\title{
Penyingkiran Ammonia dan Permintaan Oksigen Kimia daripada Air Sisa Kumbahan menggunakan Media Penjerap Komposit Karbon Teraktif
}

(Ammonia and Chemical Oxygen Demand Removal from Sewage Wastewater using Composite Adsorbent-Based Activated Carbon)

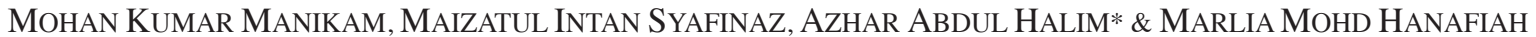

\begin{abstract}
ABSTRAK
Kajian ini dijalankan bagi menentukan keberkesanan media penjerap komposit karbon teraktif dalam menyingkirkan ammonia dan permintaan oksigen kimia (COD) daripada air sisa kumbahan. Kajian ini terbahagi kepada empat bahagian utama iaitu pencirian media komposit, penentuan parameter optimum, uji kaji penjerapan kelompok dan kajian penjerapan turus. Parameter optimum seperti pH, masa sentuhan dan dos bahan penjerap turut dikaji. Kajian isoterma penjerapan, kinetik penjerapan dan penjerapan turus turut dijalankan. Hasil kajian menunjukkan pH5 dan pH6 adalah paling optimum bagi penyingkiran ammonia dan COD. Peratus penyingkiran ammonia yang paling optimum bagi masa sentuhan adalah pada minit ke-15 dengan bacaan penyingkiran sebanyak $71 \%$ dan bagi peratus penyingkiran CoD berlaku pada minit ke-30 iaitu dengan penyingkiran sebanyak 51\%. Dos bahan penjerap optimum bagi penyingkiran ammonia adalah 25 $\mathrm{g} / \mathrm{L}$ manakala bagi penyingkiran COD adalah $50 \mathrm{~g} / \mathrm{L}$. Dalam kajian isoterma, model isoterma Langmuir dan Freundlich telah diaplikasi dan hasil kajian membuktikan bahawa isoterma penjerapan ammonia dan COD adalah mematuhi model isoterma Freundlich iaitu $R^{2}=0.9004$ dan $R^{2}=0.9818$. Kajian kinetik menunjukkan kadar kinetik bagi penjerapan ammonia dan COD ini adalah mematuhi model kinetik tertib kedua dan pekali korelasi yang diperoleh adalah $R^{2}=0.9985$ dan $R^{2}=0.9998$. Kajian ini menunjukkan bahawa kinetik penjerapan ammonia dan COD adalah dipengaruhi oleh proses kimia. Berdasarkan hasil yang diperoleh daripada kajian penjerapan turus, keberkesanan media penjerap komposit karbon teraktif dalam menyingkirkan ammonia dan COD daripada air sisa kumbahan dapat ditentukan berdasarkan peratus penyingkiran yang diperoleh mencapai sehingga 90\% bagi ammonia dan $88 \%$ bagi COD. Hasil ini menunjukkan bahawa media penjerap komposit karbon teraktif dapat diaplikasikan dalam proses rawatan air sisa kumbahan.
\end{abstract}

Kata kunci: Air sisa kumbahan; isoterma; kinetik; komposit; penjerapan

\section{ABSTRACT}

This study was conducted to determine the effectiveness of activated carbon composite adsorbent media in removing ammonia and chemical oxygen demand (COD) form sewage wastewater. This study was divided into four main parts, composite media characterization, optimum parameter determination, batch study of the adsorption and adsorption column study. Optimum parameters such as pH, contact time and adsorbent dosage were also investigated. In addition, adsorption isotherm studies, adsorption kinetics and adsorption column study were conducted as well. The results showed that optimum $\mathrm{pH} 5$ for removal of ammonia while $\mathrm{pH} 6$ for COD. The optimum percentage of ammonia removal for the contact time was in the $15 \mathrm{~min}$ with the removal of $71 \%$ and for the removal percentage of COD occurred in the $30 \mathrm{~min}$ with the removal of 51\%. The optimum adsorbent dosage for ammonia removal is about $25 \mathrm{~g} / \mathrm{L}$ while for removal of COD is $50 \mathrm{~g} / \mathrm{L}$. In the isothermal studies, Langmuir and Freundlich isotherm models were applied and the results showed that ammonia and COD adsorption isotherm was in compliance with the Freundlich isotherm model with $R^{2}=0.9004$ and $R^{2}$ $=0.9818$. Kinetic studies showed the kinetic rates for adsorption of ammonia and COD were obtained for second order kinetic model and the coefficient of correlation was $R^{2}=0.9985$ and $R^{2}=0.9998$. This study showed that the kinetic adsorption of ammonia and COD was influenced by the chemical processes. Based on the results obtained from the study of the adsorption column, the effectiveness of activated carbon composite adsorbent media in removing ammonia and COD of sewage wastewater is shown by removal percentage achieving up to $90 \%$ for ammonia and $88 \%$ for COD. This research showed that activated carbon composite adsorbent media can be applied to treat sewage wastewater.

Keywords: Adsorption; composite; isotherm; kinetic; sewage wastewater

\section{PENDAHULUAN}

Aktiviti pembangunan yang pesat mengakibatkan kemerosotan kualiti alam sekitar termasuklah pencemaran air sungai. Pencemaran air sungai yang berlaku memberi kesan negatif terhadap persekitaran akuatik seperti gangguan rantai makanan organisma akuatik (Chapman 1992; Gerhardt 2000), kemerosotan kualiti air (Clasen 1997; Codd \& Bell 1985) serta kesan jangka panjang 
dalam kehidupan manusia (Costanza et al. 1997; Fatimah Mohd Yusof 1996; Green 1981). Aktiviti perindustrian, pertanian dan domestik menyumbang kepada perubahan sifat fizikal, biologi dan kimia air (Dudgeon 2008; Ho 1996). Pencemaran air menyebabkan kos rawatan bekalan air mentah semakin meningkat bagi menyingkirkan bahanbahan berbahaya sebelum dibekalkan bagi kegunaan harian manusia.

Air sisa kumbahan dan sisa industri merupakan punca yang boleh mencemar dan mengubah kualiti sesebuah badan air (Oladele et al. 2011). Air sisa kumbahan adalah campuran tinja manusia, urin dan juga air buangan hasil daripada aktiviti harian manusia. Ia merupakan cecair buangan dari kawasan kediaman, sekolah, restoran, hospital, kawasan pertanian serta kawasan perindustrian yang terhasil daripada tandas, sinki dan bilik air (Haniffa \& Aminuddin 2005). Air sisa kumbahan mempunyai $99.9 \%$ air dan $0.1 \%$ pepejal. $70 \%$ darpada pepejal ini ialah bahan organik seperti protein, karbohidrat dan lemak. Manakala 30\% daripada pepejal ini ialah bahan inorganik seperti kelikir, nutrien tumbuhan, garam, mineral dan logam (Arthur 1983). Air sisa kumbahan mempunyai unsur kandungan pepejal terampai dan pepejal terlarut yang tinggi selain mengandungi kepekatan ammonia serta nitrogen dan fosforus yang berkemungkinan terhasil daripada penguraian bahan organik di dalam air (Chavan \& Dhulap 2012; Hou et al. 2006). Air sisa kumbahan boleh mendatangkan bahaya kepada manusia serta hidupan lain sekiranya ia tidak dirawat (Subramaniam et al. 2016) bagi menyingkirkan bahan pencemar toksik dalam air sisa dan larutan akueus seperti proses penggumpalan-pemendakan (Halim et al. 2012a), osmosis songsang, elektrodialisis, pengestrakan bahan terlarut, filtrasi membran (Kavak \& Ozturk 2005), penjerapan (Alias et al. 2011; Halim et al. 2013) dan elektrokoagulasi (Halim et al. 2012b). Kaedah yang digunakan ini memerlukan kos yang tinggi untuk dilaksanakan (Smith et al. 1995). Keperluan pengurusan dan rawatan air sisa kumbahan yang cekap sangat penting bagi meningkatkan kualiti air dan ia boleh mengatasi masalah isu pencemaran sumber air, kos rawatan air yang semakin meningkat serta peraturan pelepasan air sisa yang semakin ketat. Bagi mengatasi masalah ini, kaedah penjerapan menggunakan bahan penjerap digunakan dengan meluas untuk menyingkirkan bahan pencemar dalam merawat air sisa industri dan air sisa kumbahan kerana keupayaan menjerap bahan pencemar yang tinggi serta kos yang lebih rendah berbanding dengan keadah rawatan lain (Bakar et al. 2016; Halim et al. 2011; Yilmaz et al. 2006).

Penggunaan penjerap komposit pada masa ini diiktiraf sebagai teknologi moden dan maju dalam teknik penyediaan penjerap. Bahan komposit mengandungi beberapa jenis penjerap yang berlainan dan tujuan penghasilannya adalah untuk memperbaiki ciri dan keupayaan penjerap dalam masa yang sama untuk menghasilkan penjerap yang mudah digunakan dalam industri (Kamaruddin et al. 2013). Kelebihan menggunakan media penjerap komposit menunjukkan gabungan antara penjerapan kimia dan fizikal, sesuai dengan sifat bahan mentah yang membentuknya, berkos rendah dan keupayaan penjerapan yang lebih baik serta kebolehan diregenerasi menjadikan media komposit lebih kompetitif berbanding media konvensional lain (Azhar 2007; Azhar et al. 2010). Pada masa ini, banyak kajian telah dijalankan untuk menghasilkan penjerap bukan konvensional yang menjanjikan manfaat untuk tujuan dagangan pada masa hadapan. Sebahagian daripada karbon teraktif disediakan daripada bahan semula jadi dan juga sisa pertanian (Nazri et al. 2018). Karbon teraktif telah terbukti sebagai penjerap yang baik untuk penyingkiran bahan pencemar organik (diukur sebagai COD) dan $\mathrm{NH}_{3}-\mathrm{N}$ daripada air sisa mahupun larut resapan. Kajian yang dilakukan oleh Kaur et al. (2016) menggunakan abu tulang lembu teraktif untuk merawat larut resapan stabil di Tapak Pelupusan Dadumajra, Chandigarh, India telah berjaya menyingkirkan 79\% COD yang berkepekatan awal 2,088 mg/L. Tambahan pula, menurut kajian Azmi et al. (2016) yang menggunakan karbon teraktif berasaskan tebu secara kimia (SCAC) untuk penyingkiran $\mathrm{NH}_{3}-\mathrm{N}$ dan COD daripada larut resapan stabil di Tapak Pelupusan Sahom (jenis anaerobik), Kampar, Perak, Malaysia mendapati penggunaan SCAC sebagai bahan penjerap berupaya menyingkirkan $46.65 \% \mathrm{NH}_{3}-\mathrm{N}$ dan $83.61 \%$ COD dengan kapasiti penjerapan masing-masing adalah $14.62 \mathrm{mg} / \mathrm{g}$ dan $126.58 \mathrm{mg} / \mathrm{g}$.

Dalam kajian ini, bahan penjerap yang digunakan ialah media komposit berkos rendah iaitu karbon teraktif. Objektif kajian ini ialah untuk menyingkirkan nitrogenammonia dan COD dalam air sisa kumbahan menggunakan penjerap komposit berkos rendah. Penggunaan media komposit dalam penyingkiran ammonia dan COD dijangka mampu mengatasi masalah kos yang tinggi dalam rawatan air sisa kumbahan. Sekiranya kadar penjerapan media komposit terhadap nitrogen-ammonia dan COD adalah tinggi, maka penggunaan media komposit dianggap mampu untuk menyingkirkan nitrogen-ammonia dan COD dalam air sisa kumbahan.

\section{BAHAN DAN KAEDAH}

\section{SAMPEL AIR SISA KUMBAHAN}

Persampelan air sisa kumbahan dilakukan di kolam takungan kumbahan Bukit Puteri, Universiti Kebangsaan Malaysia (UKM), Selangor, Malaysia yang merupakan tempat pengumpulan air sisa kumbahan domestik dari kawasan perumahan kakitangan UKM, Bangi. Sampel yang diambil adalah air sisa kumbahan yang masih belum dirawat. Setelah sampel diambil, ia disimpan di dalam bilik sejuk yang bersuhu $4^{\circ} \mathrm{C}$ untuk mengekalkan kandungannya daripada mengalami tindak balas kimia yang boleh mengubah kandungan bahan pencemar.

\section{PENYEDIAAN MEDIA PENJERAP KOMPOSIT}

Media penjerap komposit yang digunakan di dalam uji kaji ini adalah dalam bentuk serbuk. Karbon teraktif yang pada 
mulanya dalam bentuk ketulan kecil dihancurkan sehingga menjadi serbuk yang bersaiz $250 \mu \mathrm{m}$ (Salam et al. 2011). Karbon teraktif, simen Portland biasa dan agen pembuih dicampur dengan menggunakan air suling. Bancuhan ini dibiarkan keras selama dua hari dan kemudiannya direndam di dalam air semalaman untuk proses pengawetan. Simen Portland biasa ini berfungsi sebagai bahan pengikat media komposit manakala agen pembuih untuk menghasilkan ruang poros pada ketulan media komposit. Ketulan ini bersifat peroi dan ditumbuk menggunakan penumbuk porselin dan mortar untuk menjadikannya dalam bentuk serbuk. Serbuk penjerap komposit ini disaring untuk memperoleh saiz serbuk yang sekata iaitu antara $2.00 \mathrm{~mm}$ hingga $3.15 \mathrm{~mm}$ (Mohamad et al. 2015).

\section{PENCIRIAN MEDIA PENJERAP KOMPOSIT}

Pencirian bahan penjerap komposit ditentukan dengan menggunakan ujian pembelauan sinar-X untuk menentukan kandungan mineral yang hadir di dalam media penjerap karbon teraktif. Ujian ini dijalankan dengan menggunakan alat Spektrofotometer belauan sinar-X, model D8 Advance yang terletak di Makmal Sinar-X, Pusat Penyelidikan UKM. Sampel media penjerap yang telah disediakan dalam bentuk serbuk dianalisis bagi mendapatkan bacaan spektrum pembelauan sinar-X dan spektrum ini dianalisis bagi menentukan kandungan mineral yang hadir di dalam media komposit.

\section{PENENTUAN PARAMETER OPTIMUM}

Parameter optimum terdiri daripada $\mathrm{pH}$, sentuhan masa optimum dan dos bahan penjerap. Kesan pH terhadap keberkesanan penyingkiran nitrogen-ammonia dan COD dikaji dengan melaraskan $\mathrm{pH}$ air sisa kumbahan iaitu pada $\mathrm{pH} 4$ hingga $\mathrm{pH} 10$ menggunakan larutan $0.1 \mathrm{M}$ asid sulfurik dan larutan $1 \mathrm{M}$ natrium hidroksida pada suhu $25^{\circ} \mathrm{C}$. Masa sentuhan optimum mewakili sela masa 2, 5, $8,10,15,30,45,75,90,105$ dan 120 min. Bagi kesan dos bahan penjerap, satu siri kelalang kon yang mengandungi media komposit sebanyak $0.5,1.0,1.5,2.0,2.5,3.0,5.0$, 8.0 dan $10.0 \mathrm{~g}$ disediakan.

\section{KAJIAN PENJERAPAN KELOMPOK}

Uji kaji penjerapan kelompok dimulakan dengan penentuan parameter optimum, diikuti dengan isoterma penjerapan dan kajian kinetik penjerapan. Isoterma penjerapan boleh ditentukan sama ada dengan mempelbagaikan jisim bahan penjerap untuk satu siri isi padu dan kepekatan nitrogenammonia dan COD yang tetap atau mempelbagaikan kepekatan nitrogen-ammonia dan COD tetapi isi padunya masih tetap sama dengan satu siri jisim media penjerap yang berbeza. Kajian kinetik penjerapan dilakukan dengan penentuan masa goncangan untuk sela masa 2, 5, 8, 10, 15, 30, 45, 75, 90, 105 dan 120 min. Keadaan optimum bagi uji kaji kelompok ditentukan dengan menimbang sebanyak $5 \mathrm{~g}$ media komposit dan dimasukkan ke dalam kelalang kon yang mengandungi $100 \mathrm{~mL}$ air sisa kumbahan.
Kemudian, siri kelalang kon tadi ditutup dengan parafilem bagi mengelakkan evaporasi berlaku. Seterusnya, digoncang dengan menggunakan alat penggoncang orbital pada $200 \mathrm{rpm}$ selama 2 jam. Kemudian, kesemua siri kelalang kon yang mengandungi air sisa kumbahan dituras secara manual dengan menggunakan kertas turas picagari iaitu membran turas nilon (Minisart) bersaiz $0.45 \mu \mathrm{m}$. Kepekatan nitrogen-ammonia ditentukan secara Spektrofotometer HACH DR 2700 dengan kaedah Nessler Method (8038) pada jarak gelombang $380 \mathrm{~nm}$ (USEPA 1992) manakala kepekatan COD pula ditentukan secara spektrofotometer HACH DR 2700 dan DRB/200 HACH dengan kaedah penghadaman reaktor (8000) pada jarak gelombang $435 \mathrm{~nm}$ (APHA 2005).

\section{KAJIAN PENJERAPAN TURUS}

Kajian penjerapan turus dijalankan dengan menggunakan turus berketinggian $30 \mathrm{~cm}$ dan berdiameter $2.5 \mathrm{~cm}$. Larutan sampel air sisa kumbahan dialirkan memasuki turus penjerapan menggunakan pam peristaltik Longer Pump untuk mewujudkan tekanan dan memudahkan pengaliran sampel daripada bawah ke atas dengan kadar aliran sebanyak $10 \mathrm{~mL} / \mathrm{min}$. Aliran air sisa kumbahan yang melalui turus penjerapan dimalarkan sepanjang kajian dijalankan. Jisim media penjerap yang digunakan ialah 106.35 g. Hasil penjerapan dikumpul berdasarkan masa yang telah ditentukan iaitu pada jam ke $0.1,0.2,0.3,0.6$, $0.9,1.3,1.8,2.4,3.1,3.8,4.7,19.7,20.7,21.7,23.7,25.7$, $38.7,41.7,44.7,47.7$ dan 50.7 masa rawatan. Analisis kandungan nitrogen-ammonia dan COD ditentukan dengan kaedah Nessler Method (8038) dan kaedah penghadaman reaktor (8000).

\section{HASIL DAN PERBINCANGAN}

\section{PENCIRIAN AIR SISA KUMBAHAN}

Berdasarkan persampelan yang telah dijalankan, pencirian air sisa kumbahan dijalankan menggunakan data yang diambil secara terus semasa persampelan dan juga melalui analisis kimia awal. Analisis kimia awal telah dijalankan bagi menentukan kepekatan awal nitrogen-ammonia dan COD yang ada di dalam air sisa industri terbabit. Jadual 1 menunjukkan kandungan nitrogen-ammonia dan COD air sisa kumbahan terbabit.

JADUAL 1. Pencirian air sisa kumbahan

\begin{tabular}{lc}
\hline Parameter & Kepekatan/Bacaan $(\mathrm{mg} / \mathrm{L})$ \\
\hline Ammonia & $2.61 \mathrm{mg} / \mathrm{L}$ \\
Permintaan oksigen kimia (COD) & $549 \mathrm{mg} / \mathrm{L}$ \\
$\mathrm{pH}$ & 6.42 \\
\hline
\end{tabular}

PENENTUAN PH BAGI TITIK CAJ SIFAR $\left(\mathrm{pH}_{\mathrm{ZPC}}\right)$

Penentuan $\mathrm{pH}$ bagi titik caj sifar $\left(\mathrm{pH}_{\mathrm{ZPC}}\right)$ adalah satu proses $\mathrm{pH}$ pada permukaan media penjerap komposit 
bersifat sifar dan neutral disebabkan oleh kewujudan $\mathrm{H}^{+}$ dan $\mathrm{OH}^{-}$yang sama. Seperti yang diperoleh pada Rajah $1, \mathrm{pH}_{\mathrm{ZPC}}$ bagi media penjerap komposit karbon teraktif berlaku pada $\mathrm{pH} 11.5$ dengan titik persilangan berlaku pada paksi-x. Apabila nilai $\mathrm{pH}$ berada di atas nilai $\mathrm{pH}_{\mathrm{ZPC}}$, ini menunjukkan bahawa permukaan media penjerap bersifat negatif atau bercaj anionik. Hal ini seterusnya akan menyebabkan penarikan kation dan berlaku tindak balas penukaran kation. Manakala apabila nilai $\mathrm{pH}$ berada di bawah nilai $\mathrm{pH}_{\mathrm{ZPC}}$, permukaan penjerap adalah bercaj positif dan menyebabkan permukaan penjerap menarik anion. Tindak balas penukaran anion seterusnya berlaku pada permukaan media penjerap komposit.

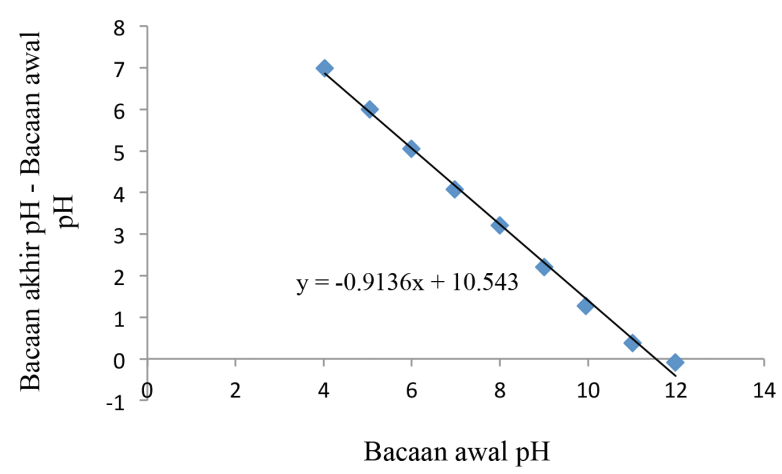

RAJAH 1. Graf bagi pH titik caj sifar (pHZPC)

\section{PENCIRIAN MEDIA PENJERAP KOMPOSIT PEMBELAUAN SINAR-X (XRD)}

Keputusan ujian pembelauan sinar-X menunjukkan kehadiran kualitatif mineral hablur yang terbentuk di dalam media penjerap komposit karbon teraktif. Ujian ini telah dijalankan pada sudut 2-theta. Berdasarkan ujian pembelauan sinar-X (XRD) mengesahkan kehadiran karbon dan kalsium karbonat pada media penjerap komposit. Berdasarkan puncak spektrum yang diperoleh seperti yang ditunjukkan dalam spektrum pembelauan sinar-x (Rajah 2). Sebahagian besar komposisinya adalah taburan partikel karbon dan selebihnya adalah terdiri daripada kalsium oksida, silikon dioksida dan aluminum oksida ini kerana kesan campuran simen Portland biasa. Ini menunjukkan bahawa bahan penjerap yang dihasilkan adalah bahan komposit yang masih mengekalkan ciri-ciri mikroskopik asal bahan yang membentuknya. Keputusan pembelauan sinar-x juga menyokong pernyataan tersebut dengan menunjukkan kehadiran fasa mineral karbon dan kalsit (kalsium karbonat) dalam bahan penyerap komposit.

\section{MIKROGRAF SEM}

Mikrograf SEM penjerap komposit ditunjukkan dalam Rajah 3. Daripada analisis mikrograf SEM tersebut, dapat diperhatikan bahawa penjerap komposit mempunyai permukaan yang agak kasar, tidak seragam dan berliang menunjukkan kemungkinan ia dapat menurunkan bahan

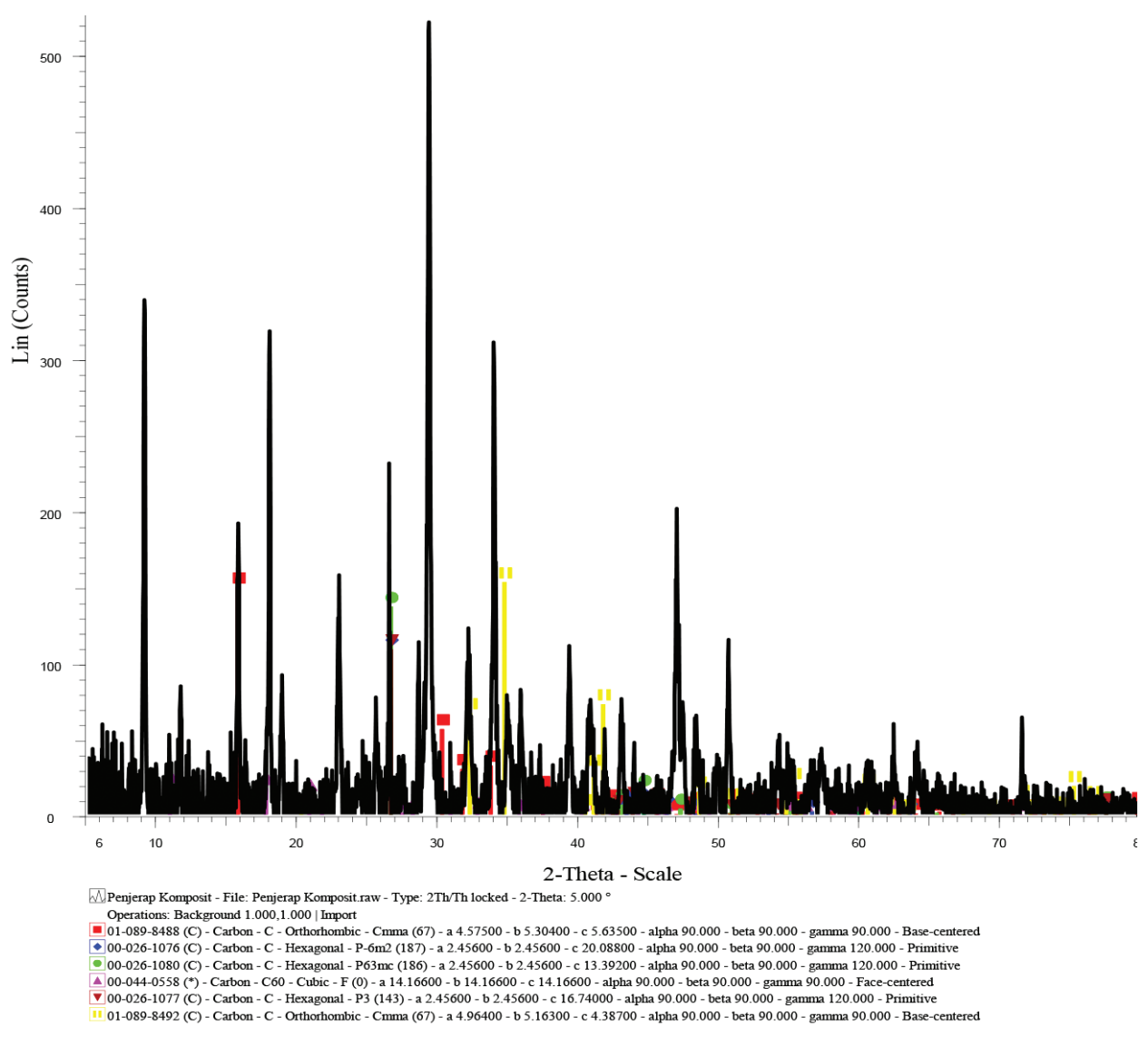

RAJAH 2. Spektrum pembelauan sinar-X (XRD) 
pencemar $\left(\mathrm{NH}_{3}-\mathrm{N}\right.$ dan $\left.\mathrm{COD}\right)$ daripada air kumbahan apabila proses penjerapan berlaku kelak. Keadaan permukaan berliang yang tidak sekata bagi penjerap komposit yang lain ini dilaporkan oleh beberapa penyelidik terdahulu (Lakhera et al. 2015; Mojiri et al. 2016).

\section{PARAMETER OPTIMUM KESAN PH}

Rajah 4 menunjukkan $\mathrm{pH}$ optimum bagi penyingkiran nitrogen-ammonia dan COD yang menggunakan media komposit sebagai bahan penjerap. Hasil kajian menunjukkan julat purata penyingkiran bagi ammonia ialah antara 20\% hingga $44 \%$ manakala julat purata penyingkiran bagi COD adalah $45 \%$ sehingga $55 \%$. pH optimum bagi penyingkiran ammonia adalah pada $\mathrm{pH} 5$ iaitu dengan peratus penyingkiran sebanyak $44 \%$. Menurut Azhar (2007), penyingkiran ammonia ini dapat dikaitkan dengan ciri-ciri nitrogen ammonia dalam larutan akues yang wujud dalam dua bentuk iaitu ammonia $\left(\mathrm{NH}_{3}\right)$ yang mempunyai bacaan $\mathrm{pH}$ yang tinggi iaitu bersifat bes dan juga dalam bentuk ion ammonium $\left(\mathrm{NH}_{4}^{+}\right)$yang mempunyai bacaan $\mathrm{pH}$ yang rendah dan bersifat asid. Demir et al. (2002) turut menyatakan penyingkiran ammonia sepatutnya tinggi pada $\mathrm{pH}$ yang rendah dan rendah pada $\mathrm{pH}$ yang tinggi sekiranya berlaku mekanisme pertukaran kation dalam keadaan ion ammonium $\left(\mathrm{NH}_{4}^{+}\right)$dominan dalam larutan akues. Perkara ini dapat dilihat berdasarkan peratus penyingkiran ammonia yang semakin menurun selepas $\mathrm{pH} 5$ dan penyingkiran ammonia pada $\mathrm{pH} 10$ adalah rendah iaitu hanya 20\%. Pada $\mathrm{pH}$ yang lebih rendah dari $\mathrm{PH}_{\text {zpc }}$, kepekatan ion hidroksida $\left(\mathrm{OH}^{-}\right)$lebih rendah didapati pada permukaan komposit. Dengan ini, penjerap komposit memperoleh caj permukaan positif pada $\mathrm{pH}$ yang lebih tinggi (selepas $\mathrm{pH}>7$ ) dan ion $\mathrm{NH}_{4}^{+}$kurang merekat ke atas permukaan komposit menyebabkan ion $\mathrm{NH}_{4}^{+}$berkurangan. Keputusan ini juga turut mencadangan bahawa kadar penjerapan $\mathrm{NH}_{3}-\mathrm{N}$ sepatutnya tinggi pada $\mathrm{pH}$ rendah dan rendah pada $\mathrm{Ph}$ tinggi jika mekanisme pertukaran kation berlaku iaitu dalam keadaan ion ammonium, $\mathrm{NH}_{4}{ }^{+}$dominan dalam larutan berair (Widiastuti et al. 2011).

Penyingkiran $\mathrm{pH}$ optimum bagi COD berlaku pada $\mathrm{pH} 6$ dengan peratus penyingkiran yang dicatatkan adalah $55 \%$. Seperti yang telah diketahui, air sisa kumbahan mengandungi bahan organik yang berpunca daripada kumbahan domestik. Berdasarkan hukum Coulomb, bahan-bahan organik yang bersifat asid akan berada dalam keadaan ion bebas (RCOO-) pada $\mathrm{pH}$ yang tinggi iaitu bes dan menyebabkan berlakunya penolakan antara asid organik dan permukaan bahan penjerap yang turut mempunyai cas negatif. Keadaan ini dapat dilihat berdasarkan analisis yang dilakukan dengan peratus penyingkiran COD semakin menurun pada $\mathrm{pH}$ yang tinggi dengan bacaan $45 \%$ pada $\mathrm{pH} 10$. Oleh itu, $\mathrm{pH}$ optimum yang diperoleh daripada kajian ini adalah antara pH5 dan pH6 bagi penyingkiran ammonia dan COD daripada air sisa kumbahan dengan menggunakan media penjerap komposit karbon teraktif.

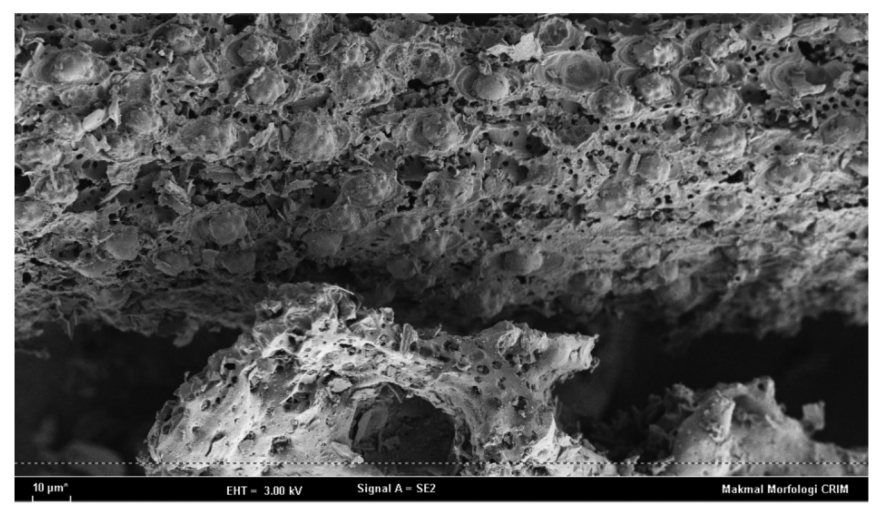

RAJAH 3. Mikrograf SEM penjerap komposit $10 \mu \mathrm{m}$, Pembesaran $=500 \times$

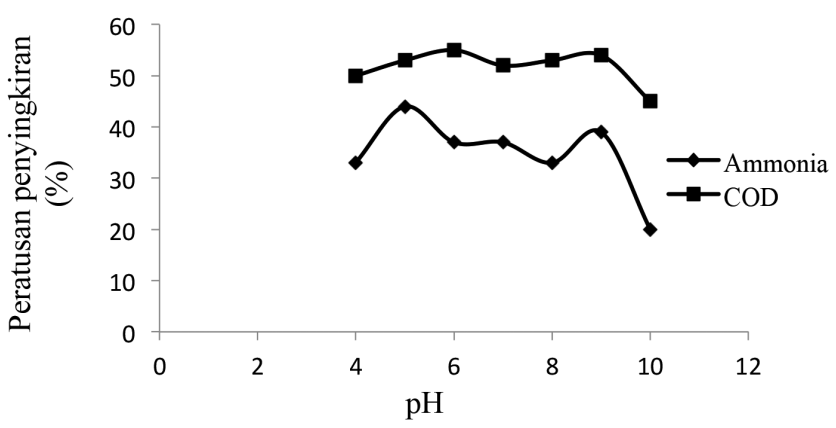

RAJAH 4. pH optimum bagi penyingkiran ammonia dan COD 


\section{MASA SENTUHAN}

Rajah 5 menunjukkan peratusan penyingkiran ammonia dan COD semakin meningkat seiring dengan peningkatan masa sehingga ia mencapai keseimbangan. Peratus penyingkiran ammonia yang paling optimum bagi masa sentuhan adalah pada minit ke-15 dengan bacaan penyingkiran sebanyak $71 \%$. Selepas minit ke-15, peratus penyingkiran mencapai tahap keseimbangan kerana tiada lagi perubahan kepekatan yang dijerap oleh bahan penjerap manakala bagi peratus penyingkiran COD berlaku pada minit ke-30 iaitu dengan penyingkiran sebanyak $51 \%$. Peratus penyingkiran COD telah mencapai keseimbangan selepas minit ke-30 apabila tiada lagi perubahan kepekatan yang berlaku.

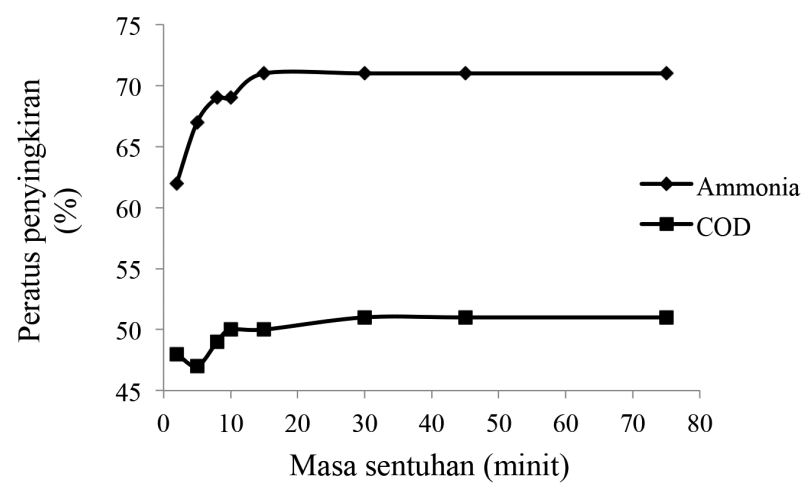

RAJAH 5. Masa sentuhan optimum bagi penyingkiran ammonia dan COD

\section{DOS BAHAN PENJERAP}

Rajah 6 menunjukkan bahawa peningkatan dos bahan penjerap dapat meningkatkan kadar penjerapan memandangkan semakin tinggi dos bahan penjerap, semakin luas tapak permukaan bagi bahan penjerap untuk menjerap ammonia dan COD. Julat peratus penyingkiran bagi ammonia adalah antara 18\% sehingga 37\%, lebih rendah berbanding peratus penyingkiran COD iaitu antara julat $45 \%$ sehingga $88 \%$. Dos bahan penjerap optimum bagi penyingkiran ammonia adalah $25 \mathrm{~g} / \mathrm{L}$ manakala bagi penyingkiran COD adalah $50 \mathrm{~g} / \mathrm{L}$.

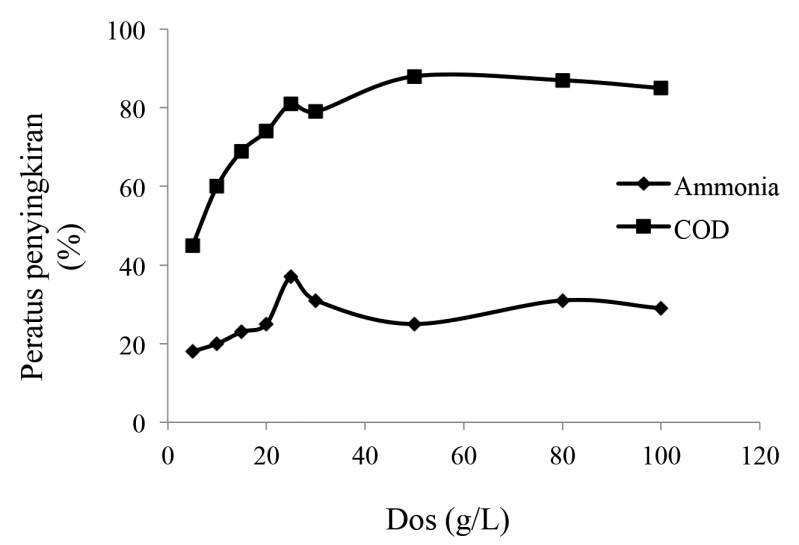

RAJAH 6. Dos bahan penjerap optimum bagi penyingkiran ammonia dan COD

\section{ISOTERMA PENJERAPAN}

Isoterma penjerapan adalah plot keseimbangan kepekatan fasa pepejal (qe) melawan kepekatan fasa cecair (Ce) yang selalunya dijelaskan dengan dua model iaitu model Langmuir dan Freundlich. Model isoterma penjerapan Langmuir berasaskan andaian bahawa penjerapan maksimum berhubung kait dengan monolapisan tepu molekul bahan dijerap di atas permukaan bahan penjerap. Model penjerapan Langmuir pada asalnya dibangunkan untuk menjelaskan penjerapan kimia secara individu dan boleh juga digunakan untuk penjerapan fizikal (monolapisan) yang julat kepekatannya rendah (Meghea et al. 1998). Data penjerapan pada keadaan keseimbangan dianalisis dalam bentuk linear menggunakan isoterma penjerapan Langmuir dan Freundlich. Persamaan linear bagi model penjerapan Langmuir ialah:

$$
\frac{1}{q_{e}}=\frac{1}{q_{m}}+\frac{1}{K_{L} q_{m} C_{e}}
$$

Model isoterma penjerapan Freundlich adalah pendekatan empirik bagi bahan penjerap yang permukaannya sangat tidak sekata dan mengambil kira pembentukan multilapisan pada permukaan bahan penjerap. Model ini boleh digunakan dalam sistem pelarut tunggal dengan julat kepekatan ditetapkan. Secara umumnya model ini sesuai untuk penjerapan bagi kepekatan sederhana dan tinggi dan kurang sesuai untuk kepekatan tinggi kerana ia tidak memenuhi keperluan Hukum Henry (Meghea et al. 1998). Persamaan bagi model isoterma penjerapan Freundlich adalah seperti berikut:

$$
\mathrm{q}_{\mathrm{e}}=\mathrm{K}_{\mathrm{f}} \mathrm{C}_{\mathrm{e}}{ }^{1 / \mathrm{n}}
$$

Persamaan ini boleh diterbitkan dalam bentuk linear dengan menggunakan logaritma seperti berikut:

$$
\log q_{e}=\log K_{F}+\frac{1}{n} \log C_{e}
$$

Isoterma penjerapan Freundlich tidak memberi maklumat mengenai kapasiti penjerapan monolapisan dan ini membezakan antara isoterma penjerapan Freundlich dengan isoterma penjerapan Langmuir (Aksu \& Gonen 2004). Hasil kajian telah dianalisis dan diplotkan dengan menggunakan model isoterma Langmuir dan Freundlich bagi penjerapan ammonia. Berdasarkan hasil kajian yang diperoleh, nilai $\mathrm{R}^{2}$ bagi model isoterma penjerapan Freundlich adalah lebih tinggi berbanding nilai $\mathrm{R}^{2}$ bagi model isoterma penjerapan Langmuir terhadap penyingkiran ammonia daripada air sisa kumbahan. Nilai $\mathrm{R}^{2}$ bagi model isoterma penjerapan Freundlich adalah 0.9004 manakala nilai $\mathrm{R}^{2}$ bagi model isoterma penjerapan Langmuir adalah 0.838 , dapat dilihat dengan jelas bahawa model Freundlich adalah lebih bersesuaian berbanding model Langmuir bagi mewakili penjerapan ammonia ke atas media penjerap komposit karbon teraktif. Nilai 
pemalar bagi model Langmuir, Q yang mewakili kapasiti penjerapan maksimum bagi penjerapan ammonia ke atas media penjerap komposit karbon teraktif adalah 0.0046 $\mathrm{mg} / \mathrm{g}$. Manakala bagi nilai pemalar model Freundlich, $\mathrm{n}$ yang mewakili kekuatan penjerapan mempunyai nilai 0.0612 kurang daripada $1,(\mathrm{n}<1)$. Ini menunjukkan bahawa penjerapan adalah baik pada kepekatan yang tinggi tetapi kurang berkesan bagi kepekatan yang rendah. Jadual 2 menunjukkan nilai $\mathrm{R}^{2}$ dan nilai pemalar yang terlibat bagi kajian isoterma penjerapan ammonia dan COD.

JADUAL 2. Nilai pemalar isoterma penjerapan Freundlich dan Langmuir

\begin{tabular}{lcc}
\hline Model & Ammonia & COD \\
\hline Model Langmuir & & \\
$\mathrm{R}^{2}$ & 0.838 & 0.8694 \\
$Q$ & 0.0046 & 2.8769 \\
$K_{L}(\mathrm{~L} / \mathrm{mg})$ & 0.4579 & 0.0031 \\
Model Freundlich & & \\
$\mathrm{R}^{2}$ & 0.9004 & 0.9818 \\
$n$ & 0.0612 & 0.3797 \\
$K_{f}\left(\mathrm{mg} / \mathrm{g}(\mathrm{mg} / \mathrm{L})^{\mathrm{n}}\right)$ & $1.33 \times 10^{-6}$ & $1.59 \times 10^{-5}$ \\
\hline
\end{tabular}

Hasil kajian yang diperoleh daripada penjerapan COD dengan menggunakan model penjerapan Langmuir dan Freundlich menunjukkan bahawa nilai $\mathrm{R}^{2}$ bagi model Freundlich adalah lebih tinggi berbanding nilai $\mathrm{R}^{2}$ bagi model Langmuir iaitu dengan bacaan masing-masing adalah 0.9818 dan 0.8694 bagi penyingkiran COD daripada air sisa kumbahan. Oleh itu, model isoterma penjerapan Freundlich adalah lebih sesuai digunakan berbanding model isoterma penjerapan Langmuir bagi penjerapan COD ke atas media penjerap komposit karbon teraktif. Nilai pemalar bagi model isoterma penjerapan Langmuir diwakili oleh Q yang menunjukkan kapasiti penjerapan maksimum bagi penjerapan COD ke atas media penjerap karbon teraktif yang mencatatkan nilai 2.8769. Manakala bagi nilai pemalar model isoterma penjerapan Freundlich, n mewakili kekuatan penjerapan mencatatkan nilai 0.3797 , kurang daripada $1,(\mathrm{n}<1)$. Nilai ini menunjukkan bahawa penjerapan adalah baik pada kepekatan yang tinggi tetapi kurang berkesan bagi kepekatan yang rendah.

\section{KINETIK PENJERAPAN}

Data penjerapan yang diperoleh daripada kajian masa sentuhan optimum digunakan dan dianalisis dengan menggunakan empat jenis model iaitu kinetik pseudo tertib pertama, kinetik pseudo tertib kedua, model Elovich dan model kinetik intra-partikel. Rajah 7 dan 8 menunjukkan plot linear bagi keempat-empat model kinetik yang digunakan dalam kajian penjerapan ammonia dan COD terhadap media penjerap komposit karbon teraktif. Model kinetik pseudo tertib pertama turut dikenali sebagai persamaan Lagergren yang telah diterbitkan oleh Lagergren pada tahun 1898 (Gurses et al. 2006). Model kinetik pseudo tertib pertama menerangkan tentang mekanisme kinetik di dalam proses penjerapan dan persamaan linearnya adalah seperti berikut:

$$
\ln (q e-q t)=\ln (q e)-k_{1} t
$$

dengan $q_{e}(\mathrm{mg} / \mathrm{g})$ dan $q t(\mathrm{mg} / \mathrm{g})$ merupakan jumlah ammonia dan COD yang dijerap pada permukaan media penjerap pada masa keseimbangan dan k1 merupakan pemalar kadar penjerapan pseudo tertib pertama. Model kinetik pseudo tertib pertama mencadangkan bahawa proses penjerapan berlaku secara penjerapan fizikal yang melibatkan interaksi daya antara molekul seperti daya Van der Waals dan tidak melibatkan perubahan kimia kepada bahan dijerap (Azhar 2007; Noor Nazurah 2010).

Model kinetik pseudo tertib kedua menerangkan tentang kemungkinan sifat keseluruhan penjerapan menepati mekanisme penjerapan kimia (Chairat et al. 2008). Persamaan linear bagi model kinetik pseudo tertib kedua adalah seperti berikut:

$$
\frac{t}{q_{t}}=\frac{1}{k_{2} q_{e}^{2}}+\frac{1}{q_{e}} t
$$

dengan $q_{e}(\mathrm{mg} / \mathrm{g})$ merupakan kepekatan ammonia dan COD yang dijerap oleh media penjerap pada masa keseimbangan dan $\mathrm{k}_{2}$ mewakili pemalar kadar keseimbangan penjerapan kinetik pseudo tertib kedua. Model kinetik Elovich pula menerangkan tentang kinetik pseudo tertib kedua yang mengandaikan permukaan pepejal sebenar adalah heterogenus daripada segi tenaganya (Nacera \& Aicha 2005; Noor Nazurah 2010). Persamaan linear bagi model kinetik Elovich adalah seperti berikut:

$$
q_{t}=\frac{1}{\beta} \ln (\alpha \beta)+\frac{1}{\beta} \ln t
$$

$\alpha\left(\mathrm{mg} \mathrm{g}^{-1} \mathrm{~min}^{-1}\right)$ merupakan kadar kepekatan ammonia dan COD yang dijerap pada masa keseimbangan dan $\beta(\mathrm{g} / \mathrm{mg})$ merupakan kadar keseimbangan bagi nyahjerapan. $\alpha$ dan $\beta$ diperoleh daripada kecerunan dan pintasan plot linear $q t$ melawan $\ln t$. Model kinetik intra-partikel digunakan bagi menunjukkan bahawa penjerapan berlaku secara pembauran intra-partikel. Persamaan linear bagi model kinetik intra-partikel adalah seperti berikut:

$$
q_{t}=k_{i} t^{0.5}+c
$$

$k_{i}$ merupakan pemalar kadar pembauran intra-partikel (mg $\mathrm{g}^{-1} \min ^{-1}$ ) dan $c$ adalah pemalar.

Berdasarkan analisis yang diperoleh daripada keempat-empat model kinetik, penjerapan ammonia ke atas media penjerap komposit karbon teraktif lebih mematuhi model kinetik pseudo tertib kedua iaitu dengan bacaan korelasi $\mathrm{R}^{2}$ yang paling tinggi iaitu 0.9985 . Model kinetik pseudo tertib kedua ini lebih sesuai digunakan 

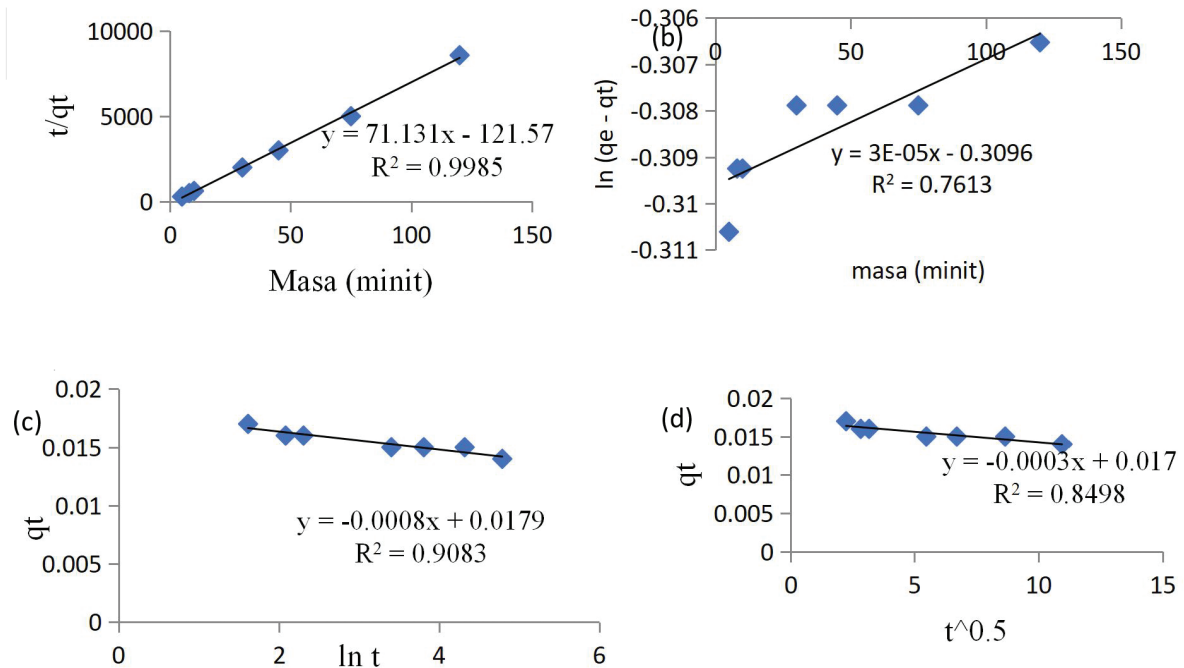

RAJAH 7. Kinetik Penjerapan Model (a) Pseudo tertib pertama, (b) Pseudo tertib kedua, (c) Elovich, dan (d) Kinetik intra-partikel menggunakan media penjerap komposit karbon teraktif bagi penjerapan ammonia
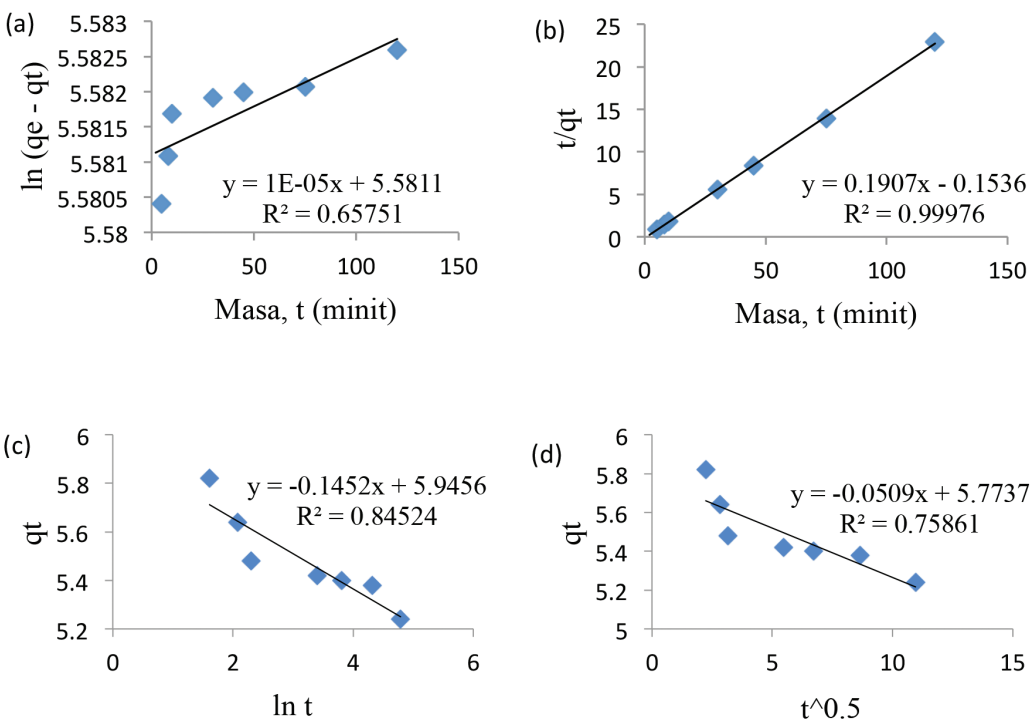

RAJAH 8. Kinetik Penjerapan Model (a) Pseudo tertib pertama, (b) Pseudo tertib kedua, (c) Elovich dan (d) Kinetik intra-partikel menggunakan media penjerap komposit karbon teraktif bagi penjerapan COD

berbanding model lain dan dapat dibuktikan dengan nilai $Q_{e}$ yang hampir sama iaitu $Q_{\text {ecalc }}$ bernilai $0.014 \mathrm{mg}$ $\mathrm{g}^{-1}$ dan nilai $Q_{e, \text { exp }} 0.015 \mathrm{mg} \mathrm{g}^{-1}$. Nilai pemalar bagi $\mathrm{k}^{2}$ adalah $-41.97 \mathrm{~g} \mathrm{mg}^{-1} \mathrm{~min}^{-1}$ yang diperoleh daripada titik persilangan plot. Model kinetik Elovich mempunyai nilai $\mathrm{R}^{2}$ iaitu 0.9083 yang menjadikannya berada di tempat kedua tertinggi diikuti oleh model kinetik intra-partikel dengan nilai bacaan $\mathrm{R}^{2}$ iaitu 0.8498 . Model kinetik pseudo tertib pertama kurang sesuai digunakan memandangkan nilai $\mathrm{R}^{2}$ yang rendah iaitu 0.7613 . Jadual 3 menunjukkan nilai pemalar dan $\mathrm{R}^{2}$ bagi model kinetik penjerapan ammonia dan COD ke atas media penjerap komposit karbon teraktif.

Kajian penjerapan COD terhadap media penjerap komposit diperoleh daripada keempat-empat model kinetik. Berdasarkan analisis yang diperoleh, model kinetik penjerapan pseudo tertib kedua memberikan bacaan korelasi $\mathrm{R}^{2}$ yang paling tinggi iaitu dengan bacaan 0.9998. Model kinetik pseudo tertib kedua ini dikuatkan lagi dengan nilai bacaan $Q_{e}$ yang tidak memberi perbezaan yang ketara berdasarkan pengiraan menggunakan model $Q_{e, \text { calc }} 5.24 \mathrm{mg} / \mathrm{g}$ dan $Q_{e, \text { exp }} 5.42 \mathrm{mg} / \mathrm{g}$ yang diperoleh daripada kajian dengan menggunakan graf $t / q t$ melawan $t$ (minit). Nilai bagi pemalar $\mathrm{k}_{2}$ adalah $-0.2371 \mathrm{~g} \mathrm{mg}^{-1} \mathrm{~min}^{-1}$.

Model kinetik Elovich mempunyai bacaan korelasi $\mathrm{R}^{2}$ kedua tertinggi dengan bacaan 0.8452 dan diikuti oleh model kinetik intra-partikel yang mempunyai bacaan korelasi $\mathrm{R}^{2}$ iaitu 0.7586 . Model kinetik pseudo tertib pertama kurang sesuai digunakan memandangkan ianya mempunyai bacaan korelasi $\mathrm{R}^{2}$ yang rendah iaitu 0.6575 . 
JADUAL 3. Nilai-nilai pemalar dan $\mathrm{R}^{2}$ bagi model kinetik penjerapan ammonia dan COD

\begin{tabular}{lcc}
\hline Persamaan kinetik & Ammonia & COD \\
\hline Pseudo tertib pertama & & \\
$\mathrm{R}^{2}$ & 0.7613 & 0.6575 \\
$k_{1}\left(\mathrm{~min}^{-1)}\right.$ & $-3 \times 10^{-5}$ & $-1 \times 10^{-5}$ \\
$Q_{e, \text { calc }}\left(\mathrm{mg} \mathrm{g}^{-1}\right)$ & 0.7337 & 265.6 \\
$Q_{e, \text { exp }}\left(\mathrm{mg} \mathrm{g}^{-1}\right)$ & 0.015 & 5.42 \\
Pseudo tertib kedua & & \\
$\mathrm{R}^{2}$ & 0.9985 & 0.9998 \\
$k_{2}\left(\mathrm{~g} \mathrm{mg}^{-1} \mathrm{~min}^{-1}\right)$ & -41.97 & -0.2371 \\
$Q_{e, \text { calc }}\left(\mathrm{mg} \mathrm{g}^{-1}\right)$ & 0.014 & 5.24 \\
$Q_{e, \text { exp }}\left(\mathrm{mg} \mathrm{g}^{-1}\right)$ & 0.015 & 5.42 \\
Elovich & & \\
$\mathrm{R}^{2}$ & & \\
$\alpha\left(\mathrm{mg} \mathrm{g}^{-1} \mathrm{~min}^{-1}\right)$ & 0.9083 & 0.8452 \\
$\beta\left(\mathrm{g} \mathrm{mg}^{-}\right)$ & $-1.53 \times 10^{-13}$ & $-2.39 \times 10^{-19}$ \\
Intra-partikel & -1250 & -6.8871 \\
$\mathrm{R}^{2}$ & & \\
$\mathrm{~K}_{\mathrm{i}}\left(\mathrm{mg} \mathrm{g}^{-1} \mathrm{~min}^{-1}\right)$ & 0.8498 & 0.7586 \\
$\mathrm{c}$ & -0.0003 & -0.0509 \\
& 0.017 & 5.7737 \\
\hline
\end{tabular}

\section{KAJIAN PENJERAPAN TURUS}

Penjerapan ammonia dan COD dapat dilihat dalam Rajah 9 dengan kepekatan ammonia dan COD yang dijerap pada bahan penjerap adalah tinggi pada awalnya yang melibatkan proses penjerapan secara kimia. Keadaan ini dapat dilihat berdasarkan peratusan ammonia dan COD yang tersingkir daripada air sisa kumbahan adalah tinggi iaitu sehingga $90 \%$ bagi ammonia dan penyingkiran COD sebanyak $88 \%$. Pada jam 0.6, kadar penyingkiran ammonia dan COD daripada air sisa kumbahan mulai menurun. Hal ini disebabkan oleh kepekatan ammonia dan COD yang terdapat pada permukaan bahan penjerap yang menjadikan tapak penjerapan semakin berkurangan.

Selepas jam 5.0, peratus penyingkiran ammonia dan COD mencapai keseimbangan kerana tiada perubahan yang ketara bagi penyingkiran parameter tersebut. Keadaan ini menunjukkan bahawa bahan penjerap telah mencapai tahap ketepuan kerana tiada lagi bahan yang boleh dijerap. Peratus penyingkiran ammonia menurun dengan ketara iaitu hanya $6 \%$ manakala peratus penyingkiran bagi COD masih pada tahap yang baik dengan bacaan 30\%. Walau bagaimanapun, peratus penyingkiran ammonia dan COD daripada air sisa kumbahan kembali meningkat pada hari ketiga sehingga mencapai tahap keseimbangan dengan bacaan penyingkiran ammonia sebanyak $47 \%$, manakala penyingkiran COD adalah sebanyak $45 \%$ hingga $47 \%$. Keadaan ini disebabkan oleh kaedah rawatan biologi yang menyebabkan bakteria telah terhasil pada permukaan bahan penjerap. Bakteria ini bertindak sebagai pengurai bagi menyingkirkan ammonia dan COD daripada air sisa kumbahan.

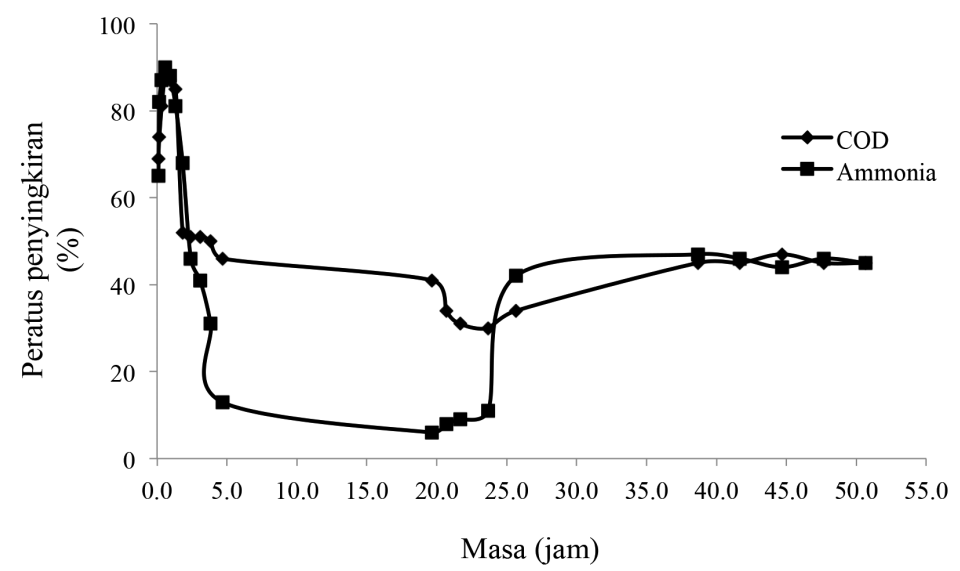

RAJAH 9. Peratus penyingkiran ammonia dan COD 


\section{KESIMPULAN}

Hasil daripada kajian ini menunjukkan bahawa media penjerap komposit berpotensi dalam menyingkirkan ammonia daripada air sisa kumbahan dengan kadar penyingkiran yang lebih tinggi bagi penyingkiran COD. Oleh itu dapat dinyatakan bahawa penjerapan ammonia dan COD ke atas media penjerap komposit karbon teraktif lebih mematuhi model isoterma penjerapan Freundlich daripada isoterma penjerapan Langmuir berdasarkan nilai korelasi $\mathrm{R}^{2}$ yang diperoleh. Ini menunjukkan bahawa penjerapan berlaku secara multilapisan dan tapak aktif penjerapan berinteraksi secara serentak dengan tapak penjerapan yang berbeza potensi penjerapannya. Selain itu, kajian kinetik menunjukkan penyingkiran ammonia dan COD daripada air sisa kumbahan lebih mematuhi model kinetik pseudo tertib kedua. Model ini mencadangkan bahawa proses penjerapan berlaku secara kimia; berlaku tindak balas antara bahan dijerap dengan permukaan bahan penjerap melalui pembentukan ikatan ionik. Di samping itu, kajian penjerapan turus diaplikasikan bagi melihat keberkesanan media penjerap komposit karbon teraktif dalam menyingkirkan ammonia dan COD daripada air sisa kumbahan. Sepanjang kajian dilakukan, dapat dilihat kepekatan ammonia dan COD berjaya diturunkan daripada air sisa kumbahan dan berada pada tahap yang dibenarkan oleh Peraturan-peraturan Kualiti Alam Sekeliling (Kumbahan 2009). Oleh itu, media penjerap komposit karbon teraktif dapat diaplikasikan bagi proses rawatan air sisa kumbahan.

\section{RUJUKAN}

Aksu, Z. \& Gonen, F. 2004. Biosorption of phenol by immobilized activated sludge in a continuous packed bed: Prediction of breakthrough curves. Process Biochemical 39(3): 599-613.

Alias, N.H.M., Halim, A.A. \& Wahab, M.I.A. 2011. Boron removal from aqueous solutions using composite adsorbent based on carbon-mineral. Sains Malaysiana 40(11): 12711276.

APHA. 2005. Standard Methods for Examination of Water and Wastewater. Ed. ke-21 Washington: American Public Health Association.

Arthur, J. P. 1983. Notes on the Design \& Operation of Water Stabilization Pond in Warm Climates of Developing Countries. Washington: 7-9. The Bank.

Azhar, A.H. 2007. Olahan larut lesapan semi-aerobik menggunakan penjerap komposit berkos rendah. Tesis Dr. Falsafah, Universiti Kebangsaan Malaysia (tidak diterbitkan).

Azmi, N., Bashir, M.J.K., Sethupathi, S. \& Ng, C.A. 2016. Anaerobic stabilized landfill leachate treatment using chemically activated sugarcane bagasse activated carbon: Kinetic and equilibrium study. Desalination and Water Treatment 57(9): 3916-3927.

Bakar, A.F.A., Barkaw, S.N.M., Hanafiah, M.M., Ern, L.K. \& Halim, A.A. 2016. Penyingkiran ammonia dan logam berat daripada air sisa industri automotif menggunakan pasir terubah suai secara kimia. Sains Malaysiana 45(10): 1509-1516.

Chairat, M., Rattanaphani, S., Bremner, J. B. \& Rattanaphani, V. 2008. Adsorption kinetic study of lac dyeing on cotton. Dyes and Pigments 76: 435-439.

Chapman,D. 1992. Water Quality Assessment: A Guide to the Use of Biota, Sediments and Water in Environmental Monitoring. London: Chapman and Hall. hlm. 246-249.

Chavan, B.L. \& Dhulap, V.P. 2012. Treatment of sewage through phytotechnical studies with constructed wetland using eichhornia crassipes. Journal of Environmental Research and Development 7(2): 660-666.

Chowdhury, Z.Z., Hamid, S.B.A. \& Zain, S.M. 2015. Evaluating design parameters for breakthrough curve analysis and kinetics of fixed bed columns for adsorption studies of cu (ii) cations using lignocellulosic wastes. BioResources 10(1): 732-749.

Clasen, J. 1997. Efficiency control of particles removal by rapid sand filters in treatment plants fed with reservoir water: A survey of different methods. IAWQ-IWSA Joint Specialist Conferences on Reservoir Management and Water Supplyan Integrated System, 19th-23rd May 1997, Prague, Czech Republic 1: 213-220.

Codd, G.A. \& Bell, S.G. 1985. Eutrophication and toxic cyanobacteria in freshwater. Journal of Water Pollution Control 84(2): 225-232.

Costanza, R., D’ Arge, R., D’ Groots, R., Farber, S., Grasso, M., Hannon, B., Limburg, K., Naeem, S., O’Neill, R.V., Paruelo, J., Raskin, R.G., Sutton, P. \&Van Den Belt, M. 1997. The value of world's ecosystem services and natural capital. Nature 3: 253-260.

Demir, A., Gunay, A. \& Debik, E. 2002. Ammonium removal from aqueous solution by ion-exchange using packed bed natural zeolite. Water SA 28(3): 329-336.

Department of Environment Malaysia (DOE). 2005. Department of Environment. Malaysia Environmental Quality Report 2005. Department of Environment, Ministry of Natural Resources and Environment, Petaling Jaya, Malaysia. 2007.

Dudgeon, D. 2008. Tropical Streams Ecology. New York: Academic Press. p. 343.

EPA. 1976. Quality Criteria for Water. Washington, DC: U.S. Environmental Protection Agency.

Fatimah Mohd Yusof. 1996. Environmental management of Lake Kenyir, Malaysia: Prevention of eutrophication. Jurnal Engineering Science 9: 43-48.

Gerhardt,A. 2000. Biomonitoring of Polluted Water. Switzerland: Trans Tech Publications Ltd.

Green, L.A. \& Hayes, C.R. 1981. The impact of eutrophication on water treatment and supplies in the Anglian water authority. Journal Water Research 35(5): 421-436.

Gurses, A., Dogar, C., Yalcin, M., Acikyildiz, M., Bayrak, R. \& Karaca, S. 2006. The adsorption kinetic of cationic dye, methylene blue onto clay. Journal of Hazardous Materials 131: 217-228.

Halim, A.A., Roslan, N.A., Yaacub, N.S. \& Latif, M.T. 2013. Boron removal from aqueous solution using curcuminimpregnated activated carbon. Sains Malaysiana 42(9): 1293-1300.

Halim, A.A., Bakar, A.F.A., Hanafiah, M.A.K.M. \& Zakaria, H. 2012a. Boron removal from aqueous solutions using curcumin-aided electrocoagulation. Middle-East Journal of Scientific Research 11(5): 583-588.

Halim, A.A., Thaldiri, N.H., Awang, A. \& Latif, M.T. 2012b. Removing boron from an aqueous solution using turmeric extract-aided coagulation-flocculation. American Journal of Environmental Sciences 8(3): 322-327. 
Halim, A.A., Abidin, N.N.Z., Awang, N., Ithnin, A., Othman, M.S. \& Wahab, M.I. 2011. Ammonia and COD removal from synthetic leachate using rice husk composite adsorbent. Journal of Urban and Environmental Engineering 5(1): 24-31.

Halim, A.A., Aziz, H.A., Johari, M.A.M. \& Ariffin, K.S. 2010. Comparison study of ammonia and COD adsorption on zeolite, activated carbon and composite materials in landfill leachate treatment. Desalination 262 (1-3): 31-35.

Haniffa, H. \& Aminuddin, M.B. 2005. Sewage treatment trends in Malaysia. The Ingenieur 3: 46-53.

Ho, S.C. 1996. Vision 2020: Towards an environmentally sound and sustainable development of freshwater resources in Malaysia. GeoJournal 40(1-2): 73-84.

Hou, H.J., Wang, H.Y. \& Zhou, Q. 2006. Treatment of municipal wastewater with low carbon and high nitrogen \& phosphorus content. Technology of Water Treatment 32(11): 33-36.

Kaur, K., Mor, S. \& Ravindra, K. 2016. Removal of chemical oxygen demand from landfill leachate using cow-dung ash as a low-cost adsorbent. Journal of Colloid and Interface Sciene 469(1): 338-343.

Kamaruddin, M.A., Yusoff, M.S., Aziz, H.A. \& Ismail, M.N. 2013. Preparation and characterization of composite embedded clinoptilolite for the removal of color and lead from textile waste water. International Journal of Scientific Research in Inventions and New Ideas 1(2): 37.

Kavak, D.\& Öztürk, N. 2005. Adsorption of boron from aqueous solutions using fly ash: Batch and column studies. Journal of Hazardous Material 127: 81-88.

Lakhera, S.K., Harsha, S. \& Suman, A.S. 2015. Synthesis and characterization of $13 \mathrm{X}$ zeolite/activated carbon composite. Int. J. ChemTech Res. 7: 1364-1368.

Meghea, A., Rehner, H., Peleanu, I. \& Mihalache, R. 1998. Testfitting on adsorption isotherms of organic pollutants from waste waters on activated carbon. Journal of Radioanalytical and Nuclear Chemistry 229(1-2): 105-110.

Mohamad, M.I.S. 2015. Penyingkiran ammonia dan COD daripada air sisa kumbahan menggunakan media penjerap komposit karbon teraktif. Tesis Fakulti Sains dan Teknologi, Universiti Kebangsaan Malaysia (tidak diterbitkan).

Mojiri, A., Aziz, H.A., Zaman, N.Q., Aziz, S.Q. \& Zahed, M.A. 2016. Metals removal from municipal landfill leachate and wastewater using adsorbents combined with biological method. Desalination and Water Treatment 57(6): 2819-2833.

Nacera, Y. \& Aicha, B. 2005. Kinetic models for the sorption of dye from aqueous solution by clay-wood sawdust mixture. Desalination 185: 499-508.

Nazri, N.H.M. 2018. Treatment of natural rubber wastewater using oil palm empty fruit bunch, kaolin and zeolite as composite. Thesis Dr. Falsafah, Universiti Tun Hussein Onn Malaysia (tidak diterbitkan).

Noor Nazurah, Z.A. 2010. Kajian pencirian bahan penjerap komposit baru berasaskan karbon dan mineral (azharit) terhadap penyingkiran ammonia dan cod daripada larut lesapan sintetik. Tesis Fakulti Sains dan Teknologi, Universiti Kebangsaan Malaysia (tidak diterbitkan).
Oladele, O.,Adegbenro, P.D. \& Adewole, M.G. 2011. The impact of industries on surface water quality of River Ona and River Alaro in oluyole industrial estate Ibadan, Nigeria. African Journal of Biotechnology 10(4): 696-702.

Peraturan-Peraturan Kualiti Alam Sekeliling (Kumbahan). 2009. Akta Kualiti Alam Sekeliling 1974. Tambahan No. 140 Perundangan (A) 53: 25.

Salam, O.E.A., Reiad, N.A. \& ElShafei, M.M. 2011. A study of the removal characteristics of heavy metals from wastewater by low-cost adsorbents. Journal of Advanced Research 2 : 297-303.

Smith, B.M., Todd, P. \& Bowman, C.N. 1995. Boron removal by polymer-assisted ultrafiltration. Separation Science and Technology 30(20): 3849-3859.

Subramaniam, D., Halim, A.A. \& Hanafiah, M.M. 2016 Performance of electrochemical oxidation in treating textile industry wastewater by graphite electrode. Nature Environment and Pollution Technology 15(3): 1021-1026.

USEPA. 1992. Standard Method for the Examination of Water and Wastewater. 18th ed. Washington D.C. United State Environmental Health Science \& Engineering 2: 43-49.

Widiastuti, N., Wu, H., Ang, H.M. \& Zhang, D. 2011. Removal of ammonium from greywater using natural zeolite. Desalination 277(1-3): 15-23.

Yilmaz, Kabay, N., Brjyak, M., Yuksel, M., Wolska, J. \& Koltuniewicz, A. 2006. A submerged membrane-ionexchange hybrid process for boron removal. Desalination 198: 310-315.

Mohan Kumar Manikam, Maizatul Intan Syafinaz, Azhar Abdul Halim* \& Marlia Mohd Hanafiah

Center for Earth Sciences and Environment

Faculty of Science and Technology

Universiti Kebangsaan Malaysia

43600 UKM Bangi, Selangor Darul Ehsan

Malaysia

Marlia Mohd Hanafiah

Center for Tropical Climate Change System

Institute of Climate Change

Universiti Kebangsaan Malaysia

43600 UKM Bangi, Selangor Darul Ehsan

Malaysia

*Pengarang untuk surat-menyurat; email: azharhalim@ukm. edu.my

Diserahkan: 18 Mac 2019

Diterima: 15 Ogos 2019 